\title{
The ants (Hymenoptera, Formicidae) in the collection of William Nylander
}

\author{
Alexander RADCHENKO \\ Laboratory of Social and Myrmecophilous Insects, Museum and Institute of Zoology, Polish Academy of Sciences, \\ Wilcza 64,00-679, Warsaw, Poland; e-mail: agradchenko@hotmail.com
}

\begin{abstract}
The ant collection of W. Nylander (Finnish Museum of Natural History, Helsinki) is investigated. The lectotypes of Myrmica rugulosa, M. sulcinodis, M. lobicornis, M. lobicornis var. lobulicornis, M. scabrinodis, M. ruginodis, M. laevinodis, and Formica picea are designated; the type specimens of the other species are considered as the syntypes (except of the earlier designated lectotypes and paralectotypes). New synonymy is established: Myrmica hirtula is junior synonym of Harpagoxenus sublaevis; Formica glebaria is a junior synonym of $F$. fusca (not of $F$. cunicularia!); Formica major is not a synonym of $F$. rufa rather it is a synonym of $F$. polyctena. However, I will apply to the International Commission of Zoological Nomenclature with the proposition to suppress the name major and keep priority for the name $F$. polyctena. Some problems on the taxonomy of the different species are discussed, and the non-type material is partly redetermined.
\end{abstract}

Key words: type material, Finnish Museum of Natural History, Formicidae, new synonymy, redetermination

\section{INTRODUCTION}

William Nylander (1822-1899) was a famous Finnish naturalist of the XIX century. Despite Nylander's main scientific interest being in botany (particularly lichenology) he was also an outstanding myrmecologist. His eight myrmecological publications provided the foundations to the modern taxonomy of the European ant fauna. Despite his relatively few papers (see listed below) he described more than 40 species and infraspecific forms, and about half of them remain recognised as good species today.

In 2002, I investigated Nylander's ant collection, which is preserved at the Finnish Museum of Natural History, Helsinki. This collection is kept in the box No. 4 and consists of 265 specimens, including the types of 35 species and infraspecific forms, described from Finland (mainly collected by Nylander personally), from southern Russia (collected by Motchoulsky) and from Italy (collected by Zeller). There are also the non-type material of 19 species (partly redetermined by me), which I include in the list below.

I have designated the lectotype specimens for all the 'good' Myrmica species (with one addition - M. laevinodis), and for Formica picea Nylander. All the other type specimens are considered as syntypes (except for earlier designated lectotypes and paralectotypes). Full labeldata for all specimens is provided in order to assist future investigators who may work with Nylander's collection. Here the species are ordered according their order in the collection.

\section{LIST OF THE NAMES OF ANTS IN THE COLLECTION OF WILLIAM NYLANDER (according the original labels)}

\section{Ponera coarctata Latreille}

Two workers on 2 pins, without locality labels, first pin with the label "Ponera coarctata Latr." 
2. Myrmica lippula Nylander, 1849: 41, workers

Type locality: southern Russia (see Note 1 below).

Syntypes (? - see Note 2 below): worker, "Russ. Merid.", "Motschoulsky", "Coll. Nyland.", "spec. type No. 5100"; on 2 another pins there are only gasters of 2 workers (type Nos. 5101 and 5102 correspondly).

Note 1. All material in the Nylander's collection, labelled as "Russ. Merid." or "Ross. Merid" (i.e. southern Russia), was collected by Russian entomologist V. Motchoulsky. It is impossible now to define correctly the precise localities or even country: they could have come from the southern part of European Russia or Ukraine.

Note 2. Myrmica lippula was transferred to the genus Stenamma and synonymised with $S$. westwoodi Westwood by Forel (1889). DuBois (1993) revived the name S. lippulum from synonymy and considered it as senior synonym of $S$. caucasicum Arnoldi. He also noted in his paper (loc. cit., p. 322) that the lectotype of S. lippulum is in the Finnish Museum of Natural History, but did not give any data of the labels of this "lectotype". I did not find any of DuBois' labels in the correspondent material of Nylander's collection. On the other hand, the type specimen of Myrmica lippula with No. 5100 is a worker of Tetramorium caespitum Linnaeus.

\section{Myrmica diluta Nylander, 1849: 41, workers}

Type locality: southern Russia.

Syntypes: worker, "Ross. mer.", "Motchoulsky", "Coll. Nyland.”, "Russ. merid. Motch.", “M. diluta Nyl.”, “Mus. Zool. H: fors Spec. typ. No. 5104 Myrmica diluta Nyl.”; worker, "Ross. mer.", "Motchoulsky", "Coll. Nyland.”, "Mus. Zool. H: fors Spec. typ. No. 5103 Myrmica diluta Nyl.".

I confirm Mayr's (1861) synonymy of this name with M. ruginodis Nylander.

\section{Myrmica rugulosa Nylander, 1849: 32, workers, queens}

Type locality: Finland.

Lectotype (designated here): worker, "H: fors", "W. Nyland.”, "Coll. Nyland.”, "Mus. Zool. H: fors Spec. typ. No. 5077 Myrmica rugulosa Nyl.”, "Mus. Hels. N:o 2208”, "Mus. Zool. Helsinki Loan No. 1897'.

Paralectotypes: 2 workers on one pin, “H: fors”, "W. Nyland.”, “Mus. Fenn.”, “Mus. Zool. H: fors Spec. typ. No. 5075 Myrmica rugulosa Nyl.", "Mus. Zool. Helsinki Loan No. 1895"; queen, "H: fors", "W. Nyland.", "Coll. Nyland.", "Mus. Zool. H: fors Spec. typ. No. 5076 Myrmica rugulosa Nyl.", "Mus. Zool. Helsinki Loan No. 1896"; gyne and worker on one pin, "H: fors", "W. Nyland.", “Coll. Nyland.”, "Mus. Zool. H: fors Spec. typ. No. 5074 Myrmica rugulosa Nyl."; worker, "H: fors", "W. Nyland.", "Coll. Nyland."; 2 workers on one pin, "H: fors", "W. Nyland.", "Coll. Nyland.".

The type specimens of this species fully correspond with the modern treatment of $M$. rugulosa.

\section{Myrmica sulcinodis Nylander, 1846a: 934, workers, queens}

Type locality: Finland.

Lectotype (designated here): worker (bottom specimen on the pin with 3 workers), "H: fors", "W. Nyland.", "Coll. Nyland.", "Mus. Zool. H: fors Spec. typ. No. 5054 Myrmica sulcinodis Nyl.".

Paralectotypes: 2 workers on the pin with the lectotype; 3 workers on one pin with the same labels as the lectotype, but type No. 5055. 
I exclude a worker with the same labels as the lectotype, but type No. 5056, from the type series of M. sulcinodis, which I determined as M. scabrinodis Nyl.

Non-type material: 2 workers on one pin, "Kuusamo", "W. Nyland.”, "Coll. Nyland."; 3 workers on one pin, "588"; queen and worker on one pin, "590"; queen, "Sibiria or.", "Coll. Nyland.".

The type specimens of this species fully correspond with the modern treatment of $M$. sulcinodis. They are slightly discoloured, but the head is somewhat darker than the alitrunk. The antennal scape is distinctly but not sharply, angled at the base. The current treatment of $M$. sulcinodis also includes European and Caucasian populations where the antennal scape is only sharply curved, not angled.

\section{Myrmica lobicornis Nylander, 1846a: 932, workers, queens}

Type locality: Finland (“Hab. per totam saltem Fennien sat frequens").

Lectotype (designated here): worker (with the male on one pin), "Uleåborg", "W. Nyland.", "Mus. Zool. H: fors Spec. typ. No. 5053 Myrmica lobicornis Nyl." (see also Seifert, 2005).

Paralectotypes: worker and male on one pin, "Uleåborg”, "W. Nyland.", "Mus. Fenn.", "Mus. Zool. H: fors Spec. typ. No. 5050 Myrmica lobicornis Nyl."; worker and male on one pin, "Uleåborg", "W. Nyland.", "Mus. Fenn.", "Mus. Zool. H: fors Spec. typ. No. 5051 Myrmica lobicornis Nyl."; queen, "Uleåborg”, "W. Nyland.", "Mus. Fenn.", "Mus. Zool. H: fors Spec. typ. No. 5052 Myrmica lobicornis Nyl."; worker and male on one pin, Uleåborg", "W. Nyland.", "Mus. Fenn.".

Non-type material: worker, "Sibiria bor.".

Note. There are also males on the pins with the lectotype and paralectotypes workers but formally they cannot be included to the type series, because Nylander described males of this species later, in 1849. The type specimens and males fully correspond with the modern treatment of M. lobicornis.

\section{Myrmica lobicornis var. lobulicornis Nylander, 1857: LXXIX, workers}

Type locality: France.

Lectotype (designated here): worker, "M. Dore", "F. (Sic!) lobicornis var. lobulicornis Nyl." "W. Nyland.", "Mus. Zool. H: fors Spec. typ. No. 5118 Myrmica lobulicornis Nyl." (see also Seifert 2005).

Paralectotype: worker, "M. Dore”, “W. Nyland.”, "Mus. Zool. H: fors Spec. typ. No. 5119 Myrmica lobulicornis Nyl.".

Note. Bondroit (1920) raised this variety to species level; later it was synonymised with $M$. lobicornis (Bernard 1967, Seifert 1988), but recently (Seifert, 2005) again promoted it to a species.

\section{Myrmica schencki Viereck (my identification)}

Two workers on one pin, No. 587; 1 queen, "Bariges", "W. Nyland.", "M. lobicornis Nyl.". Nylander originally determined these specimens as M. lobicornis.

\section{Myrmica scabrinodis Nylander, 1846a: 930, workers, queens, males}

Type locality: Finland.

Lectotype (designated here): worker (bottom specimen on the pin with 2 workers), "Kuusamo", "W. Nyland.", "Mus. Fenn.": this specimen was pinned through gaster by a blunt, thin pin; during my investigation of it the specimen fell off its mount, so I stuck it (with water soluble glue) to the cardboard triangle and replaced it on the proper pin.

Paralectotypes: worker (upper) on the pin with the lectotype; 2 workers on a pin with the same labels as the lectotype. 
Note. Nylander (1846a) did note give the exact type locality of M. scabrinodis, only noted: "A Cell. Dahlbom exemplaria bujus speciei accepti, inter quae errant females and males deprehensi ad Wandsteman Ostrogonthiae d. 17 Aug. 1841 et males alter captus ad Esperöd Scaniae d. 8 ejusdem".

I also found in Nylander's collection other specimens determined as M. scabrinodis:

1) a pin with only one ant gaster, "a Dahlbom", "Mus. Zool. H: fors Spec. typ. No. 5049 Myrmica scabrinodis Nyl.", "Mus. Hels. N:o 3217"; this specimen most probably belongs to the type series, but as most of the specimen is entirely lost there is no reason to include this gaster to the paralectotypes.

2) male (without head) and queen on one pin, "Bogdå", "W. Nyland.", “Coll. Nyland.", "Emsale", "20/viii.46, 우”, "Mus. Hels. N:o 2212”, "Mus. Hels. N:o 2216";

3) queen, "H: fors", "W. Nyland.”, " $2 / \mathrm{x} 47$ ", "Coll. Nyland.”;

4) queen, "H: fors", "W. Nyland.", "Coll. Nyland.".

The specimens mentioned above are $M$. scabrinodis, but formally cannot be included in the type series because they were collected on $20^{\text {th }}$ of August 1846 and $2^{\text {nd }}$ of October 1847 while Nylander's (1846a) paper was accepted $9^{\text {th }}$ of February 1846 . The queen on pin " 4 " has no date label and because I am not sure whether it belong to the type series or not, I have not included it as a paralectotype.

All the workers and queens mentioned above fully correspond with the modern treatment of M. scabrinodis; unfortunately the single male in Nylander's collection has no head and so the key character of a short antennal scape cannot be confirmed, but by all other features, including very long and abundant hairs on the legs, it looks to me to be a typical M. scabrinodis male.

In addition, there is a damaged worker (pinned though pronotum, gaster with postpetiole pinned below on the same pin) with the labels "H: fors", "W. Nyland.", "Coll. Nyland.". Originally, it was determined as M. scabrinodis but actually is a specimen of M. sabuleti Meinert (my identification).

10. Myrmica ruginodis Nylander, 1846a: 929, workers, queens, males

Type locality: Finland.

Lectotype (designated here): worker (upper specimen on the pin with 2 workers), "Kuusamo", "W. Nyland.”, "Mus. Zool. H: fors Spec. typ. No. 5045 Myrmica ruginodis Nyl.”.

Paralectotypes: worker (bottom) on the pin with the lectotype; male, with the same labels as the lectotype, but type No. 5046; queen, male and worker on one pin, with the same labels as the lectotype, but type No. 5046 and one additional label: "Mus. Hels. N:o 3211"; queen, with the same labels as the lectotype, but type No. 5046 and one additional label: "Mus. Hels. N:o 3212 ”.

The type specimens of this species fully correspond with the modern treatment of $M$. ruginodis (sensu Yarrow 1955b et auct.).

11. Myrmica laevinodis Nylander, 1846a: 927, workers, queens, males

Type locality: Finland.

Lectotype (designated here): worker (upper specimen on the pin with 2 workers), "H: fors", "W. Nyland.", "Mus. Fenn..”, "Mus. Zool. H: fors Spec. typ. No. 5044 Myrmica laevinodis Nyl.".

Paralectotypes: worker (bottom) on the pin with the lectotype; queen, with the same label as the lectotype, but type No. 5041; male and worker on one pin, "H: fors", "W. Nyland.", "Coll. Nyland.", "9/viii.45", "Mus. Zool. H: fors Spec. typ. No. 5042 Myrmica laevinodis Nyl.", "Mus. Hels. N:o 3212"; 2 males on one pin (one male without waist and gaster), "H: fors", "W. Nyland.", "Mus. Zool. H: fors Spec. typ. No. 5043 Myrmica laevinodis Nyl.". 
The type specimens of this species fully correspond with the modern treatment of $M$. rubra L. (sensu Yarrow 1955b et auct.).

12. Myrmica striatula Nylander, 1849: 40, workers

Type locality: southern Russia.

Syntypes: worker, "Russia merid.", "Motchoulsky", "Coll. Nyland.”, "Ross. merid. Motsch.", "striatula", "Mus. Zool. H: fors Spec. typ. No. 5097 Myrmica striatula Nyl."; worker, "Russia merid.", "Motchoulsky", "Mus. Zool. H: fors Spec. typ. No. 5098 Myrmica striatula Nyl."; worker with the same labels as the previous one, but type No. 5099.

Non-type material: male, "Belgia", "Coll. Nyland.".

Note. Mayr (1855) transferred Myrmica striatula to the genus Myrmecina Curtis and synonymised it with $M$. graminicola (Latreille). I confirm this synonymy.

\section{Myrmica fuscula Nylander, 1846a: 935, workers, males}

Type locality: Finland.

Syntypes: worker, "H: fors”, “W. Nyland.”, “20/v", “Coll. Nyland.”, “fuscula Nyl.”, "Mus. Zool. H: fors Spec. typ. No. 5057 Myrmica fuscula Nyl."; male, with the same labels as the previous specimen, but type No. 5059.

Non-type material: worker (without postpetiole and gaster), "451"; 4 workers on one pin, "587"; 2 workers (one without head) on one pin, "589"; 3 workers on one pin, without label.

Note. In Nylander's collection there are also 3 specimens, labelled as the types of $M$. fuscula: queen, "H: fors", "W. Nyland.", "Mus. Fenn.”, "Mus. Zool. H: fors Spec. typ. No. 5058 Myrmica fuscula Nyl", and queen and worker on one pin, "H: fors", "W. Nyland.", "2/VII. 46", "Coll. Nyland.", "fuscula Nyl.", "Mus. Zool. H: fors Spec. typ. No. 5060 Myrmica fuscula Nyl.". I excluded them from the type series for two reasons: 1) Nylander did not describe queens (Bolton 1995 erroneously noted that this species was described also from queens), and 2) collecting date of the second queen with worker is later than when Nylander's paper was accepted (see also Notes for M. scabrinodis, above).

F. Smith (1851) synonymised M. fuscula with M. caespitum (Linnaeus); now: Tetramorium caespitum. I confirm this synonymy.

14. Myrmica mutica Nylander, 1849: 39, workers, queens, males

Type locality: southern Russia.

Syntypes: worker (major), "Ross. merid.”, "Motchoulsky”, “Coll. Nyland.”, "1”, "Ross. merid. Motsch.", "Mus. Zool. H: fors Spec. typ. No. 5096 Myrmica mutica Nyl.”; queen (damaged, gaster with waist are pinned separately on the same pin), "Ross. merid.", "Coll. Nyland.", "1", "Ross. merid. Motsch.", "Mus. Zool. H: fors Spec. typ. No. 5094 Myrmica mutica Nyl."; male, "Ross. merid.", "Motchoulsky", "Coll. Nyland.", "1", "Ross. merid. Motsch.”, "Mus. Zool. H: fors Spec. typ. No. 5095 Myrmica mutica Nyl.”.

Note. Mayr (1855) synonymised M. mutica with Atta structor (Linnaeus); now: Messor structor. I confirm this synonymy.

\section{Myrmica acervorum (Fabricius)}

Three workers on one pin, "Kuusamo", "W. Nyland.”; queen, "H: fors”, "W. Nyland.", "11/v. 46".

All these specimens are Leptothorax acervorum.

16. Myrmica muscorum Nylander, 1846b: 1054, workers, queens, males

Type locality: Finland. 
Syntypes: worker and queen on one pin, "H: fors", "W. Nyland.", "Coll. Nyland.", "Mus. Zool. H: fors Spec. typ. No. 5068 Myrmica fuscula Nyl."; worker and queen on one pin, with the same labels as the previous one, but type No. 5069; male, with the same labels as the previous one, but type No. 5067; male, with the same labels as the previous one, but type No. 5070; 3 workers on one pin, "H: fors", "W. Nyland.", "Coll. Nyland."; worker and queen, with the same labels as the previous one; worker and queen, with the same labels as the previous one.

The type specimens fully correspond with the modern treatment of Leptothorax muscorum.

\section{Myrmica tuberum (Fabricius)}

Worker, "532"; 2 workers and queen on one pin, "538; 3 workers on one pin, without labels; worker, without labels; 2 workers on one pin, without labels. All these specimens fully correspond with the modern treatment of Temnothorax tuberum. 2 additional workers on one pin, without labels, are L. muscorum (my identification).

\section{Myrmica unifasciata Latreille}

Two workers on one pin, "Ros. mer.", "Motchoulsky", "Coll. Nyland.”, "unifasciata Latr."; worker, "Ros. mer.", "Motchoulsky", "Coll. Nyland."; queen and 2 workers, each on the separate pins, with the same labels as the previous one; worker and queen on one pin, with the same labels as the previous one.

These specimens are Temnothorax crassispinus (Karawajew) (my identification; see also Radchenko 2000).

\section{Myrmica sublaevis Nylander, 1849: 33, workers}

Type locality: Kuusamo, Finland.

Syntypes: worker (upper specimen on the pin; bottom worker on the same pin is its host species, L. acervorum), "Kuusamo", "W. Nyland.", "Coll. Nyland.", "Mus. Zool. H: fors Spec. typ. No. 5078 Myrmica sublaevis Nyl."; worker, with the same labels as the previous one, but type No. 5079; worker, "Kuusamo", "W. Nyland.", "Mus. Fenn.", "Mus. Zool. H: fors Spec. typ. No. 5080 Myrmica sublaevis Nyl.".

The type specimens fully correspond with the modern treatment of Harpagoxenus sublaevis.

\section{Myrmica hirtula Nylander, 1849: 45, workers}

Type locality: Helsinfors, Finland.

Syntypes: worker, "H: fors”, "W. Nyland.", “Coll. Nyland.”, “Mus. Zool. H: fors Spec. typ. No. 5114 Formica (Sic!) hirtula Nyl."; 4 workers, each on separate pin, with the same labels as the previous one, but type Nos. 5115, 5116 and 5117.

Myrmica hirtula was transferred to the genus Harpagoxenus by Emery (1922), and was considered until now as subspecies of $H$. sublaevis (see Bolton 1995). After seeing the type specimens I have no doubt that subsp. hirtulus is junior synonym of $H$. sublaevis, syn. nov.

\section{Myrmica nitidula Nylander, 1846: 1058, workers}

Type locality: Finland.

Syntypes: worker, "H: fors”, “W. Nyland.”, “Mus. Fenn”, “Mus. Zool. H: fors Spec. typ. No. 5072 Myrmica nitidula Nyl."; worker, with the same labels as the previous one, but type No. 5073.

Note. In the Nylander's collection there is a queen (without postpetiole and gaster), labelled as the type: "H: fors", "W. Nyland.", "Coll. Nyland.", "Mus. Zool. H: fors Spec. typ. No. 5071 Myrmica nitidula Nyl.". However, as Nylander described queen of this species three years later, in 1849, this queen must be excluded from the type series. 
The type specimens fully correspond with the modern treatment of Formicoxenus nitidulus.

22. Myrmica pallida Nylander, 1849: 42, workers

Type locality: Messina, Italy.

Syntypes: worker, "Messina”, “Zeller”, “Coll. Nylandr.”, “29”, “5”, “Mus. Zool. H: fors Spec. typ. No. 5120 Myrmica pallida Nyl.", worker, with the same label as the previous one, but type No. 5191.

The type specimens fully correspond with the modern treatment of Aphaenogaster pallida.

23. Myrmica pallidula Nylander, 1849: 42, workers

Type locality: Messina, Italy.

Syntypes: 3 workers on one pin, "Messina”, “Zeller", “Coll. Nylandr.”, “6”, "Mus. Zool. H: fors Spec. typ. No. 5105 Myrmica pallidula Nyl.".

Non-type material: worker, "Tiflis", "Coll. Nyland.".

The type specimens fully correspond with the modern treatment of Pheidole pallidula.

24. Myrmica flavidula Nylander, 1849: 43, workers

Type locality: southern Russia (Don river).

Syntypes: 2 workers on one pin, "Ross. merid.", "Motchoulsky", "Coll. Nylandr.", "Mus. Zool. H: fors Spec. typ. No. 5107 Myrmica flavidula Nyl."; 5 workers on three pins with the same labels as the previous ones, but type Nos. 5107, 5108 and 5109.

Mayr (1855) synonymised M. flavidula with Solenopsis fugax (Latreille). I confirm this synonymy.

25. Myrmica sordidula Nylander, 1849: 44, workers

Type locality: Messina, Italy.

Syntypes: 2 workers on one pin, "Messina”, “Zeller", “Coll. Nyldr.”, “10”, "Mus. Zool. H: fors Spec. typ. No. 5110 Myrmica sordidula Nyl."; worker with the same labels as the previous one, but type No. 5111.

The type specimens fully correspond with the modern treatment of Crematogaster sordidula.

26. Myrmica rubriceps Nylander, 1849: 44, workers

Type locality: Messina, Italy.

Syntypes: worker, “Messina”, “Zeller”, “Coll. Nyldr.”, “2”, “Mus. Zool. H: fors Spec. typ. No. 5112 Myrmica rubriceps Nyl."; worker with the same labels as the previous one, but type No. 5113.

Non-type material: worker, "Georgia", Coll. Nyland.", "var. georgica".

Mayr (1855) transferred M. rubriceps to the genus Crematogaster Lund and synonymised with C. scutellaris (Olivier). I confirm this synonymy.

27. Formica vividula Nylander, 1846a: 900, workers, queens, males

Type locality: Finland.

Lectotype (designated by J. Trager): male, "H: fors”, “W. Nyl.”, "Mus. Fenn.”, "Mus. Zool. H: fors Spec. typ. No. 5015 Formica vividula Nyl.", "Lectotype Formica vividula Nylander det. J. C. Trager, 1984" (red label).

Paralectotypes: 2 workers on one pin, "H: fors”, "W. Nyland.”, “Mus. Fenn.”, "Mus. Zool. H: fors Spec. typ. No. 5016 Formica vividula Nyl.", "Paralectotype top specimen Formica vividula Nylander det. J. C. Trager, 1984” (red label), “Allotype allolectotype worker, lower specimen Formica vividula Nylander det. J. C. Trager, 1984" (light blue label); 2 workers on 
one pin (upper specimen is damaged, with the only head and pronotum), "H: fors", "W. Nyland.”, “Mus. Fenn.”, “Mus. Zool. H: fors Spec. typ. No. 5017 Formica vividula Nyl.”, "Paralectotype workers Formica vividula Nylander det. J. C. Trager, 1984" (red label); queen (dealate, without petiole and gaster), "H: fors", "W. Nyland.", "Mus. Fenn.", "2/x 45", "Mus. Zool. H: fors Spec. typ. No. 5014 Formica vividula Nyl.", "Paralectotype queen Formica vividula Nylander det. J. C. Trager, 1984" (red label); queen (without petiole and gaster), "H: fors", "W. Nyland.", "Mus. Fenn." (the last paralectotype specimen is designated here).

The type specimens fully correspond with the modern treatment of Paratrechina vividula.

\section{Formica pygmaea Latreille}

Two workers on one pin, "Tiflis", "Coll. Nyland."; queen (dealate) and 2 workers on one pin, “43”, "F. pygmaea Latr.".

Note. Workers on the first pin actually are Plagiolepis tauricus Santschi (my identification; see also Radchenko 1989, 1996).

Queens and workers on the second pin are not $P$. pygmaea. They have quite long $2^{\text {nd }}$ to $4^{\text {th }}$ funicular joints, but in P. pygmaea $3^{\text {rd }}$ funicular joint is transversal and distinctly shorter than the $4^{\text {th }}$ one. Those specimens are very dirty and have no locality labels, and now it is impossible to identify them correctly, however this species belongs to the pallescens-group of the genus Plagiolepis Mayr.

\section{Lasius citrinus Emery (my identification of undetermined material)}

Three workers and male on the separate pins with the labels "Ross. merid.", "Motchoulsky", “Coll. Nyland.".

\section{Formica umbrata Nylander, 1846b: 1048, queens, males}

Type locality: Finland.

Syntypes: queen, "H: fors”, "W. Nyland.”, “Coll. Nyland.”, “16/viii”, “Mus. Zool. H: fors Spec. typ. No. 5062", "Mus. Hels. No. 2371", "Holotype Stärcke, 36” (this specimen cannot be considered as the holotype); gyne, "H: fors", "W. Nyland.", "umbrata queen H: fors", Coll. Nyland.”, “16/viii”, "Mus. Zool. H: fors Spec. typ. No. 5061”; gyne, "H: fors”, "W. Nyland.”, "Coll. Nyland.", "Mus. Zool. H: fors Spec. typ. No. 5064”, "Mus. Hels. No. 2371”; gyne, "Vichtis", "4/x", “Coll. Nyland.", "Mus. Zool. H: fors Spec. typ. No. 5065"; male, "Vichtis", “4/x", “Coll. Nyland.”, "Mus. Zool. H: fors Spec. typ. No. 5063”.

Non-type material: 7 workers on 4 pins with the labels "H: fors", "W. Nyland.", "Coll. Nyland.”.

The type and non-type specimens fully correspond with the modern treatment of Lasius umbratus.

31. Formica mixta Nylander, 1846b: 1050, workers, queens, males

Type locality: Finland.

Syntype: queen, "Formica mixta Nylander Upsala", "Mus. Zool. H: fors Spec. typ. No. 5066”, “Mus. Hels. N:o 2372”.

The type specimen fully corresponds with the modern treatment of Lasius mixtus.

\section{Formica nigra Linnaeus}

I partly redetermined material, originally determined as "Formica nigra" (=Lasius niger).

Lasius niger: 2 workers and 2 gynes (one of the latter is damaged by Anthrenus beetle, another one is without gaster), "H: fors", "W. Nyland.", "Coll. Nyland.".

Lasius alienus (Förster): worker, "H: fors", "W. Nyland.”, “Coll. Nyland.”. 
Lasius paralienus Seifert: 2 workers on the separate pins, "Triest", "Triest 29/2 43", "Coll. Nyland.”.

\section{Formica fuliginosa Latreille}

Worker and 2 males (one is without gaster) on the same pin, without locality labels, there is only label "6". All are Lasius fuliginosus.

\section{Formica fusca Linnaeus}

I partly redetermined material, previously determined as Formica fusca.

F. fusca: worker, "Des. Kirgis.", "Coll. Nyland.";

F. picea: worker, “Uleåborg”, "W. Nyland.”, “25/viii”, “Coll. Nyland.”, “Mus. Hels. No. 2210 "; worker (is damaged, with the only head and pronotum), "Ulb".

\section{Formica glebaria Nylander, 1846a: 917, workers, queens}

Type locality: Finland.

Syntypes: worker (is damaged, with the only head and pronotum), "H: fors", "W. Nyland.", "Coll. Nyland.", "glebaria Nyl.", "Mus. Zool. H: fors Spec. typ. No. 5039 Formica glebaria Nyl.", "Mus. Hels. No. 1087"; queen (without gaster) and worker's gaster on one pin, with the same labels as the previous one, but type No. 5040 and one additional label "Mus. Hels. No. 1086"; queen, with the same labels as the previous one, but type No. 5038; queen, "H: fors", "W. Nyland.", "Coll. Nyland.", "H: fors", "Mus. Zool. H: fors Spec. typ. No. 5037 Formica glebaria Nyl.", "Mus. Hels. No. 1100”, "Mus. Hels. No. 2677” (Sic!), "glebaria Nyl.", "fusca auct ? Lin. Det. Yarrow 195_".

Non-type material: worker of $F$. fusca L. (for the queen on the same pin see notes below), “499".

Note. The queen on the pin with worker of $F$. fusca (with the label "499") is actually $F$. lemani Bondroit. The male with the labels "Ostrob.", "Hellstöm”, "W. Nyland.", "Mus. Fenn.", "Mus. Hels. N:o 1089" is F. gagatoides Ruzsky (my identification).

$F$. glebaria was considered as a junior synonym of $F$. fusca by many authors (Mayr 1855, Yarrow 1954, Dlussky 1967; see also Bolton 1995), but later it was synonymised with $F$. cunicularia Latreille (Bernard 1967, Agosti \& Collingwood 1987). Investigation of the types shows that $F$. glebaria is a junior synonym of $F$. fusca, syn. revived.

\section{Formica picea Nylander, 1846a: 917, workers}

Type locality: Finland (“ad Helsingfors et Uleåborg”).

Lectotype (designated here): worker (is damaged, without petiole, gaster, left legs, tibia and tarsus of the right middle leg), "H: fors", "W. Nyland.", “Coll. Nyland.", "42/vii", "picea Nyl.", "Mus. Zool. H: fors Spec. typ. No. 5035 Formica picea Nyl” (see also Seifert 2004).

Note. In Nylander's collection, there are also 2 workers on one pin, which are labelled as the type specimens: "Kuusamo", "W. Nyland.", "Coll. Nyland.", "Mus. Zool. H: fors Spec. typ. No. 5036? Formica picea Nyl". Unfortunately, the locality data of these specimens does not correspond with those in Nylander's (1846a) paper, where the type localities are given as Helsingfors and Uleåborg. Therefore, I excluded those workers from the type series of $F$. picea.

The name Formica picea Nylander is preoccupied name of Formica picea Leach, 1825 (now Camponotus piceus), and Yarrow (1954) proposed for this species the first available replacement name - F. transkaucasica Nassonov, 1889. Later, Bolton (1995) with any comments synonymised $F$. transkaucasica with $F$. candida F. Smith, 1878; Collingwood (1999) rejected Bolton's opinion and revived name transkaucasica from synonymy. Finally, Seifert (2004) proposed to consider Nassonov's F. transkaucasica as incertae sedis in the 
genus Formica, and revived the name $F$. picea Nylander from synonymy, and separated the latter species from $F$. candida $F$. Smith.

37. Formica aenescens Nylander, 1849: 37, workers, queens, males

Type locality: southern Russia.

Syntypes: worker and male (male is without petiole and gaster) on one pin, "Ross. mer.", "Motchoulsky", "Coll. Nylandr.", "Mus. Zool. H: fors Spec. typ. No. 5191".

Non-type material: queen, "Des. Kirgis.", "Coll. Nyland.", "Desert Kirgisica”; male, "45”, "Mt. Bogdo", queen, "45".

All these specimens fully correspond with the modern treatment of Cataglyphis aenescens.

\section{Formica brunnea Latreille}

Worker ("Venezia"), originally determined as F. brunnea (= Lasius brunneus) actually is Prenolepis sp. (my identification).

39. Tapinoma kinburni Karawajew (my identification of undetermined material)

Worker, "Ross. mer.”, "Motchoulsky”, “Coll. Nylandr.”.

Note. T. kinburni was known only from Ukraine (Radchenko 1983), and recently recorded from Belgorod Region of Russia (Prisnyi 2003). The locality mentioned as "Russia meridionale" by Motschoulsky is somewhere in European Russia or in Ukraine (see above).

40. Tapinoma erraticum (Latreille) (my identification of undetermined material)

Four workers and queen (dealate) on 2 pins, "Paris", "Coll. Nyland."

41. Formica pressilabris Nylander, 1846 a: 911, workers, queens, males

Type locality: Finland and Russia (?) ("Fennia et Karelia").

Paralectotypes (?): 2 workers on one pin, "H: fors", "W. Nyland.", “Coll. Nyland.".

Non-type material: worker and queen on one pin, "4".

Notes: Seifert (2000) designated the lectotype (worker) and paralectotypes of this species ( 5 workers and 3 males), but did not provide the labels data. These types are absent from the Nylander's collection.

42. Formica exsecta Nylander, 1846a: 909, workers, queens, males

Type locality: Finland.

Syntypes: male, "Ostrob.”, "W. Nyland.”, “Coll. Nyland.”, "Mus. Zool. H: fors Spec. typ. No. 5028 Formica exsecta Nyl"; 3 workers on one pin, "H: fors", "W. Nyland.", "Coll. Nyland.", "Mus. Zool. H: fors Spec. typ. No. 5028 Formica picea Nyl”; queen, with the same labels as the previous one, but type No. 5029; 2 males on one pin, with the same labels as the previous one, but type No. 5030.

The type specimens fully correspond with the modern treatment of $F$. exsecta.

43. Formica trunicola Nylander, 1846a: 907, workers, queens

Type locality: Finland.

Syntypes: queen, "Kuusamo”, “W. Nyland.”, “Coll. Nyland.”, “Mus. Zool. H: fors Spec. typ. No. 5024"; male, with the same label as the previous one, but type No. 5025; worker and gyne on one pin, with the same label as the previous one, but type No. 5026 .

I confirm Roger's (1863) synonymy of this species with F. truncorum Fabricius.

44. Formica congerens Nylander, 1846a: 906, workers

Type locality: Finland. 
Syntypes: 2 workers on one pin (one is without petiole and gaster), "H: fors", "W. Nyland.", "Coll. Nyland.", "Mus. Zool. H: fors Spec. typ. No. 5023 Formica congerens Nyl”, "Mus. Hels. N:o 2665"; 3 workers on one pin, "Mus. Zool. H: fors Spec. typ. No. 5022 Formica congerens Nyl".

I confirm Yarrow's (1955a) synonymy of this species with F. lugubris Zetterstedt.

\section{Formica dominula Nylander, 1846a: 905, workers, queens, males}

Type locality: Finland.

Syntypes: male and worker on one pin, "H: fors", "W. Nyland.", "Coll. Nyland.", "Mus. Zool. H: fors Spec. typ. No. 5018 Formica dominula Nyl"; 2 gynes on the separate pins, with the same labels as the previous one, but type Nos. 5019 and 5020; worker, with the same labels as the previous one, but type No. 5021 .

I confirm F. Smith' (1851) synonymy of this species with $F$. sanguinea Latreille.

46. Formica major Nylander, 1849: 29, workers

Type locality: Finland.

Syntypes: 3 workers (one is without petiole and gaster) on one pin, "Mus. Zool. H: fors Spec. typ. No. 5423 Formica major Nyl" , "Mus. Hels. N:o 2676", "major Nyl. pinifila Schenck rufa auct. nec. Bondr." (Yarrow's own handwriting label).

Note. Emery and Forel (1879) synonymised F. major with F. rufa Linnaeus, and this synonymy was confirmed later by Yarrow (1955a) and by the other authors (see also Bolton 1995). However, the syntypes of $F$. major are not $F$. rufa in its modern treatment (e.g. Bernard 1967, Dlussky 1967, Kutter 1977, Collingwood 1979, Seifert 1996, Czechowski et al. 2002), but clearly belong to F. polyctena Förster. Their alitrunk dorsum is hairless, while F. rufa is more hairy species and their workers have at least several standing hairs on the alitrunk dorsum.

Therefore I consider $F$. major Nylander, 1849 to be the senior synonym of $F$. polyctena Förster, 1850, and the name major should have priority. However, the name $F$. polyctena has been used hundreds times during the last 50 or so years, in taxonomic, faunistic, ecological, and other myrmecological literature. If it were changed now it would cause much confusion, therefore I shall formally apply to the International Commission of Zoological Nomenclature and propose that the name $F$. major Nylander, 1849 is suppressed in favour of the name $F$. polyctena Förster, 1850 with the aim of maintaining the stability of nomenclature in the family Formicidae.

\section{Formica atricolor Nylander, 1849: 36, workers}

Type locality: southern Russia

Syntypes: worker, "Ross. mer.", "Motchoulsky", "Coll. Nylandr.", "Motsch. 22", "Mus. Zool. H: fors Spec. typ. No. 5186"; worker, with the same labels as the previous one, but type No 5088; worker, with the same labels as the previous one, except of "Motsch. 19" and type No. 5087.

Roger (1863) transferred this species to the genus Camponotus Mayr; more recently, it was synonymised with C. piceus (Atanassov \& Dlussky 1992). I confirm this synonymy.

\section{Formica dalmatica Nylander, 1849: 37, workers}

Type locality: Croatia (Dalmatia, Lagosta).

Syntypes: major worker, "Lagosta", "Zeller", "Coll. Nyldr.", "Lagosta" (handle-writing), "5", "Mus. Zool. H: fors Spec. typ. No. 5189 Formica dalmatica Nyl."; minor worker, with the same labels as the previous one, but " 4 " and type No. 5090. 
The type specimens of this species fully correspond with the modern treatment of Camponotus dalmaticus.

49. Formica pallens Nylander, 1849: 36, workers

Type locality: Italy.

Syntypes: worker, "Messina”, "Zeller”, “Coll. Nyldr.”, “202”, “1”, “Mus. Zool. H: fors Spec. typ. No. 5084 Formica pallens Nyl."; worker with the same label as the previous one, but "192" and type No. 5191".

Notes. Roger (1863) transferred this species to the genus Camponotus. Owing to the name $F$. pallens Nylander, 1849 is the primary junior homonym of $F$. pallens Le Guillou, 1842 (which is also was transferred to the genus Camponotus), Emery (1921) proposed the replacement name - Camponotus nylanderi.

50. Formica nigrata Nylander, 1849: 35, workers, queens, males

Type locality: Italy and southern Russia [Messina (Zeller) e Rossia meridionali, workers, queens, males (Motchoulsky)].

Syntypes: worker, "Messina", "Zeller”, "Coll. Nyldr.", "192”, “3”, "Mus. Zool. H: fors Spec. typ. No. 5081 Formica nigrata Nyl."; worker with the same label as the previous one, but type No. 5082; worker, male and gyne on one pin, "Messina", "Zeller", "Coll. Nyldr.", “18”, "3 Mai”, "Mus. Zool. H: fors Spec. typ. No. 5083 Formica nigrata Nyl.”.

Notes. Probably Nylander (1849: 35) erroneously noted that queens and males of the described species were collected by Motchoulsky in southern Russia; the syntypes queen and male in the collection have locality label "Messina".

Mayr (1855) synonymised this species with Camponotus aethiops (Latreille). I confirm this synonymy.

\section{Formica glabrella Nylander, 1849: 38, workers}

Type locality: Russia.

Syntypes: 2 workers on the separate pins, "Tscherkassk", "Motschoulsky", "Coll. Nyland.", "Motsch. 23", "Spec. type No. 5093 Formica glabrella Nyl." (No. 5092 on the second pin).

F. Smith (1855) transferred this species to the genus Tapinoma Förster and synonymised it with $T$. erraticum (Latreille). I confirm this synonymy.

\section{Formica aethiops Latreille}

Three major workers on one pin, label "9". They are C. aethiops.

\section{Formica pubescens Fabricius}

Major worker, without labels.

$F$. pubescens is considered now as the junior synonym of Camponotus vagus (Scopoli) (see Bolton 1995), but the specimen originally determined here as $F$. pubescens actually is $C$. saxatilis Ruzsky (my identification).

\section{Formica herculeana Linnaeus}

Queen, "Uleåborg”, "W. Nyland.”, “Coll.. Nyland.”, "fusca Nyl.”, "Mus. Zool. H: fors Spec. typ. No. 5845 Camponotus herculeanus ssp. freya", "Mus. Hels. N:o 1090", "Holotype subsp. Freya Ske queen nov. subsp." (red handle-writing label).

This specimen is an ordinary queen of Camponotus herculeanus. Name "freya" has been never used in the literature and should be ignored. 
In the Box 4 with Nylander's collection, there are some labels with the names of species, but the material is absent: Formica flava F., Formica cunicularia Latr., and F. rufa L.

\section{OTHER TYPE SPECIMENS IN THE COLLECTION OF FINNISH MUSEUM OF NATURAL HISTORY}

Myrmica lobicornis subsp. alpina Stärcke, 1927: 80, workers, queens

Type locality: Italy.

Paralectotype (Lectotype worker with the same labels as mentioned below is in the National Museum of Natural History, Leiden, The Netherlands, designated by Radchenko et Elmes, 2002) worker, "Val Aosta 1915 La-Thulle", "holotype M. lobicornis alpina Stä.", "holotype subspecies alpina Stärcke" (red label), "Mus. Zool. H: fors Spec. typ. No. 5322 M. lob. alpina Stärcke".

Notes. This name was previously synonymised with M. lobicornis (Bernard 1967, Seifert 1988), but now is considered as a junior synonym of M. lobulicornis (Seifert 2005).

Myrmica rugulosa var. hellenica Finzi, 1926: 93, workers, queens, males (first available use of Myrmica scabrinodis r. rugulosa var. hellenica Forel, 1913: 431)

Type locality: Greece.

Syntypes: worker, “Corfu”, “J. Sahlb.”, “584”, “Myrmica scabrinodis Nyl. r. rugulosa Nyl. var. hellenica For. Type"; worker, "Patras", "U. Sahlb.”.

Notes. This form was raised to species by Agosti and Collingwood (1987) (see also Seifert, 1988).

\section{LIST OF PUBLICATIONS ON ANTS BY WILLIAM NYLANDER}

NYLANDER W. 1846a. Adnotationes in monographiam formicarum borealium Europae. Acta Soc. Sci. Fenn. 2: 875-944.

NYLANDER W. 1846b. Adnotamentum adnotationum in monographiam formicarum borealium Europae. Acta Soc. Sci. Fenn. 2: 1041-1062.

NYLANDER W. 1846c. Strodda Anteckningar. Forsoky att bestamma Linnes Svenska arter af slagtet Formica. - Notis. Sallsk. pro Fauna et Flora Fennica. Forhandl 1: 289-294.

NYLANDER W. 1849. Additamentum alterum adnotationum in monographiam formicarum borealium. Acta Soc. Sci. Fenn. 3: 25-48.

NYLANDER W. 1851. Remarks on "Hymenopterologische Studien by Arnold Förster, 1stes Heft, Formicariae, Aachen, 1850" Ann. Mag. Nat. Hist. 2(8): 126-129.

NYLANDER W. 1856a. M. L. Fairmaire communique la note suivante, de M. Nylander, et la Societe en decide l'impression dans le Bulletin. Ann. Soc. Entomol. Fr. (Bull.) 3(4): XXVIII-XXIX.

NYLANDER W. 1856b. Synopsis des formicides de France et d'Algérie. Ann. Soc. Natur. (Zool.) 5(4): 51-109.

NYLANDER W. 1857 (1856). M. L. Fairmaire communique la note suivant de M. Nylander sur les Formicides du Mont-Dore, et la Societe en decide l'impression dans le Bulletin. Ann. Soc. Entomol. Fr. (Bull.) 3(4): LXXVIII-LXXIX.

\section{ACKNOWLEDGMENTS}

I am sincerely grateful to Dr. Andres Albrecht (Finnish Museum of Natural History), Dr. Kari Vepsäläinen and Dr. Riitta Savolainen (Helsinki University) for giving me opportunity to work with Nylander's collection. I thank Dr. Graham W. Elmes (UK) for the financial support of my trip to Helsinki. This work was also supported a British Royal Society Collaborative Linkage Grant, by a grant awarded within the Exchange Programme of Scholars between the 
Polish Academy of Sciences and the Academy of Finland, by a grant of the Ministry of High Education and Sciences of Poland, No. 2P04C 064 29, and by the basic science programs of my Institute.

\section{REFERENCES}

Agosti D. \& Collingwood C. A. 1987. A provisional list of the Balkan ants and a key for the worker caste. 1. Synonymic list. Mitt. Schweiz. Entomol. Gess. 60: 261-293.

AtAnAssov N. \& Dlussky G. M. 1992. Fauna of Bulgaria. 22. Hymenoptera, Formicidae. BAN, Sofia, 310 pp. (in Bulgarian)

BERNARD F. 1967. Les Fourmis (Hymenoptera: Formicidae) d'Europe occidentale et septentrionale. Masson et Cie, Paris, 411pp.

Bolton B. 1995. A new general catalogue of the ants of the World. Harvard University Press, Cambridge, MA, 504 pp.

Bondroit J. 1920 (1919). Notes diverses sur les fourmis d'Europe. Annales de la Société entomologique de Belgique. 59: $143-158$.

Collingwood C. A. 1979. The Formicidae (Hymenoptera) of Fennoscandia and Denmark. Fauna Entomologica Scandinavica, 8: 1-174.

Collingwood C. A. 1999. Problems in ant nomenclature. Archives of Biological Sciences, Belgrade 51: 330-340.

CZEchowski W., RADChenko A. \& CZEChowsKa W. 2002. The ants (Hymenoptera, Formicidae) of Poland. Museum and Institute of Zoology PAS, Warszawa, $200 \mathrm{pp}$.

DLUSSKY G. M. 1967. Murav'i roda formica (Hymenoptera, Formicidae, G. Formica). Nauka, Moskva, 236 pp.

Du BoIS M. B. 1993. What's in a name? A clarification of Stenamma westwoodi, S. debile, and S. lippulum. Sociobiology 21: 299-334.

EMERY C. 1921. Specific names repeated in the Linnean genus Formica. Psyche 28: 24-26.

EMERY C. 1922. Hymenoptera, Fam. Formicidae, subfam. Myrmicinae. Fasc. 174C. In: WystmANN P. (ed.), Genera Insectorum, pp. 207-397. Lois Desmet-Verteneuie, Bruxelles, 398 pp.

EMERY C. \& FOREL A. 1879. Catalogue des Formicides d'Europe. Mitteilungen der schweizerischen entomologischen Gessellschaft 5: 441-481.

Forel A. 1889 (1888). Ameisen aus den Sporaden, den Cycladen und Griechenland, gesammelt 1887 von Herrn. V. Oertzen. Berliner Entomologische Zeitschrift 32: 255-265.

Forel A. 1913. Formis de la faune méditerranéenne récoltés par MM. U. Et J. Sahlberg. Revue Suisse de Zoologie $21: 427-438$.

LE GuILLOU E. J. F. 1842. Catalogue raisoné des insectes hyménoptères recueillis dans le voyage de circumnavigation des corvettes l'Astrolabe et La Zélée. Annales de la Société Entomologique 10: 311-324.

KUTTER H. 1977. Insecta Helvetica Fauna. 6. Hymenoptera, Formicidae.Fotorotar-AG, Zurich, 298 pp.

MAYR G. 1855. Formicina Austriaca. Beschreibung der bisher im österreichischen Kaiserstaate aufgefundenen Ameisen, nebst Hinzufügung jener in Deutschland, in der Schweiz und in Italien vorkommenden Arten. Verhandlungen des Zoologisch-Botanischen Vereins in Wien 5: 273-478.

MAYR G. 1861. Die Europaischen Formiciden. Wien, 80 pp.

PRISNYI A. V. 2003. Mirmekofauna Belgorodskoj oblasti, Rossija. Evroaziatskij entomol. zhurn. 2(2): $125-134$.

RADCHENKo A. G. 1983. Tapinoma kinburni Karaw. (Hymenoptera, Formicidae) - endemichnyj vid fauny Ukrainy. Zoologicheskiy. Zhurnal. 62 (12): 1904-1907.

RadCHENKO A. G. 1989. Murav'i roda Plagiolepis Mayr evropejskoj chasti SSSR. Vest. Zool. 9: 153-156.

RAdChEnKo A. G. 1996. T Murav'i roda Plagiolepis Mayr (Hymenoptera, Formicidae) central'noj i vostochnoj palearktiki. Entomologicheskoe Obozrenie. 75 (1): 178-187.

RADCHENKO A. 2000. What is "Leptothorax nylanderi" (Hymenoptera, Formicidae) in Russian and former Soviet literature? Annales Zoologici 50 (1): 43-45.

Roger J. 1863. Verzeichniss der Formiciden-Gattungen und Arten. Berliner Entomologische Zeitschrift 7: 1-65.

SEIFERT B. 1988. A taxonomic revision of the Myrmica species of Europe, Asia Minor, and Caucasia (Hymenoptera, Formicidae). Abhandlungen und Berichte des Naturkundesmuseums Görlitz 62: 1-75.

SEIFERT B. 1996. Ameisen: beobachten, bestimmen. Naturbuch-Varl., Augsburg, 352 pp.

SEIFERT B. 2000. A taxonomic revision of the ant subgenus Coptoformica Mueller, 1923 (Hymenoptera, Formicidae). Zoosystema 22(3): 517-568.

SEIFERT B. 2004. "Black Bog Ant" Formica picea Nylander, 1846 - a species different from Formica candida Smith, 1878 (Hymenoptera: Formicidae). Myrmecologische Nachrichten 6: 29-38.

SEIFERT B. 2005. Rank elevation in two European ant species: Myrmica lobulicornis Nylander, 1857, stat. n. and Myrmica spinosior Santschi, 1931, stat. n. (Hymenoptera: Formicidae). Myrmecologische Nachrichten 7: 1-7.

Smith F. 1851. List of the Species of British Animals in the Collection of the British Museum 6. Hymenoptera Aculeata. London, 134 pp. 
SMITH F. 1855. Essai on the genera and species of British Formicidae. Transactions of the Entomological Society of London 2 (3): 95-135.

Smith F. 1878. Scientific Results of Second Yarkend Mission; based upon the collections and notes of the late Ferdinand Stoliczka. Office of the Superintendent of Government printing, Calcutta, $22 \mathrm{pp}$.

YARROW I. H. H. 1954. The British ants, allied to Formica fusca. Transactions of the Society for British Entomology 11: $229-244$.

YARrow I. H. H. 1955a. The British ants, allied to Formica rufa L. Transactions of the Society for British Entomology 12: $1-48$.

YARROW I. H. H. 1955b: The type species of the ant genus Myrmica Latreille. Proceedings of the Royal Entomological Society of London (B) 24(5-6): 113-115.

\section{STRESZCZENIE}

\section{[Mrówki (Hymenoptera, Formicidae) w kolekcji Williama Nylandera]}

Praca dotyczy przeglądu kolekcji mrówek Williama Nylandera w Fińskim Muzeum Przyrodniczym w Helsinkach. Zostały wyznaczone lektotypy Myrmica rugulosa, M. sulcinodis, M. lobicornis, M. lobicornis var. lobulicornis, M. scabrinodis, M. ruginodis, $M$. laevinodis oraz Formica picea; typowe okazy innych gatunków zostały uznane za syntypy (z wyjątkiem tych, które wcześniej zostały wyznaczone jako lektotypy lub paralektotypy). Ustalono nowe synonimy: Myrmica hirtula jako młodszy synonim Harpagoxenus sublaevis; Formica glebaria jako młodszy synonim $F$. fusca (nie F. cunicularia!); Formica major jest najprawdopodobniej synonimem $F$. rufa a nie synonimem $F$. polyctena. Niemniej, Międzynarodowej Komisji Nomeklatury Zoologicznej zostanie przedłożona propozycja unieważnienia nazwy major i zachowania nazwy $F$. polyctena. W pracy zostały przedyskutowane problemy taksonomiczne materiału nietypowego, który został ponownie oznaczony. 